\title{
Peanut (Arachis hypogaea L.) yield under irrigation levels in off-season cultivation
}

\section{Rendimiento de maní (Arachis hypogaea L.) bajo niveles de riego en cultivos fuera de temporada}

Pablo Nascimento de Oliveira França ${ }^{1}$, Rogério Teixeira Faria ${ }^{1}$, Willians César Carrega ${ }^{1}$, Anderson Prates Coelho ${ }^{1}$, Ignácio José Godoy ${ }^{2}$, Luiz Fabiano Palaretti ${ }^{1}$

Originales: Recepción: 11/03/2020 - Aceptación: 27/08/2020

\begin{abstract}
Water deficit is considered the most critical environmental factor for peanut production in Brazil, as it constitutes one of the major constraints to the expansion of its cultivation in the suitable crop zones of the country. Determining crop water demand is fundamental to increasing yield with lower water consumption. The present study aimed to evaluate the effects of full and deficit irrigation levels (L1 = 8\%, L2 = 27\%, L3 = 63\%, L4 = 94\% and L5 $=100 \%$ replenishment of crop evapotranspiration) on the development, growth and yield of peanut crop sown in two times, February and March. Treatments were distributed in a split-plot randomized complete block design, with four replicates, using a line-source sprinkler system. Irrigation depths from 65 to $314 \mathrm{~mm}$ were applied with the levels L1 to L5 during the first and second cropping cycles. Full irrigation with sowing in March was more advantageous due to yield increase of up to $30 \%$ compared to sowing in February, but crop cycle was 25 days longer. Water stress caused by deficit irrigation reduced plant height, seed mass and pod yield, while full irrigation (L5) led to yields from 4,141 to 5,102 $\mathrm{kg} \mathrm{ha}^{-1}$ for February and March, approximately three times higher than those obtained with the lowest irrigation level (L1).
\end{abstract}

\section{Keywords}

Arachis hypogaea L. • deficit irrigation • water stress

1 São Paulo State University (Unesp). School of Agricultural and Veterinarian Sciences. Via de Acesso Prof. Paulo Donato Castellane s/n - CEP. 14884-900. Jaboticabal. São Paulo.Brazil.rogerio.faria@unesp.br

2 Agronomic Institute. Avenida Barão de Itapura. 1.481. Botafogo - CEP. 13020. Campinas. São Paulo. Brazil. 


\section{RESUMEN}

El déficit de agua se considera el factor ambiental más crítico para la producción de maní en Brasil, ya que constituye una de las principales limitaciones para su expansión en las zonas adecuadas para su cultivo en el país. Determinar la demanda de agua de los cultivos es fundamental para aumentar el rendimiento con un menor consumo de agua. El presente estudio tuvo como objetivo evaluar los efectos de los niveles de riego deficitarios y completos (L1 = 8\%, L2 = 27\%, L3 = 63\%, L4 = 94\% y L5 = 100\% de reposición de la evapotranspiración del cultivo) en el desarrollo, crecimiento y rendimiento de la cosecha de maní sembrado en dos veces, febrero y marzo. Los tratamientos se distribuyeron en un diseño de bloques completos aleatorios de parcelas divididas, con cuatro repeticiones y utilizando un sistema de aspersores de fuente de línea. Las láminas de riego aplicadas fueron entre 65 a 314 mm (L1 a L5) en ambos ciclos de cultivo. El nivel de riego total con siembra en marzo fue más ventajoso debido al aumento del rendimiento de hasta un 30\% en comparación con la siembra en febrero, pero el ciclo de cultivo fue 25 días más largo. El estrés hídrico causado por el riego deficitario redujo la altura de la planta, la masa de semillas y el rendimiento de vainas. El cultivo de maní con riego completo (L5) tuvo rendimientos de 4,141 a 5,102 kg ha $^{-1}$ (febrero y marzo respectivamente) siendo aproximadamente tres veces más que los obtenidos con el nivel de riego deficitario más bajo (L1).

\section{Palabras claves}

Arachis hypogaea L. • riego deficitario • estrés hídrico

\section{INTRODUCTION}

Peanut (Arachis hypogaea L.) farming is the fourth largest oil crop in global production with an estimated yield of $45.4510^{6} \mathrm{Mg}$ in the $2017 / 2018$ cropping season (35). In Brazil, peanut is currently cultivated in 138,500 ha, with a production of $0.5210^{6} \mathrm{Mg}$ and average yield of $3.71 \mathrm{Mg} \mathrm{ha}^{-1}$, which corresponds to a 13\% expansion of area and a $3 \%$ increase in its production compared to the previous season (12). São Paulo is the largest producing state, with $95 \%$ of the national production, where the peanut crop is planted mainly in succession to sugarcane in the renewal of sugarcane fields. In Brazil, peanut is cultivated in two periods: in the first one, during the rainy season, the crop is sown between October and November, and in the second one, during the dry season (off-season), it is sown between February and March. In the São Paulo state, about 95\% of the cultivated area is limited to the first crop season (12).

The off-season is a strategy for producers who intend to increase economic return with the crop and who carry out activities other than sugarcane production. Peanut cultivation in the dry season requires improved crop management (27), such as the use of irrigation to guarantee high yields and, consequently, higher profitability, since dry spells are very frequent during this period of the year and can drastically reduce the productive potential of the crop (12).

Since $70 \%$ of the peanut growing area fall under arid and semi-arid regions, water deficit during the cultivation period is considered the major constraint to peanut yield worldwide because it frequently affects crop growth and development of this crop $(22,30)$. Water is considered one of the main resources required by plants for growth and is a limiting factor for crop development and agricultural yield (11). An annual estimate of global losses in peanut yield caused by drought equivalent to US\$ 520 million (19).

Besides the negative impact on yield, water deficit stands out among the major constraint to the expansion of peanut cultivation to the suitable crop zones in Brazil. Water deficit causes reductions of 25 to $30 \%$ in peanut yield in the country $(28,31)$.

In the literature there are limited research on the effects of water deficit on peanut, most of which were carried out with cultivars of erect growth habit, which are cultivated in a small area in Brazil. Therefore, it is essential to study alternatives to minimize the impacts of water deficit on peanut cultivation in the producing regions, since it is a factor that significantly limits its yield $(18,34)$. Among the alternatives to mitigate the negative effects of 
*Sd: soil bulk density; FC: field capacity; PWP: permanent wilting point. *Sd: densidad del suelo; FC: capacidad de campo; PWP: punto de marchitez permanente. water deficit on peanut yield, it is necessary to conduct studies aiming to evaluate cultivation practices that contribute to the increase of yield and production stability, such as irrigation management, sowing dates and selection of new cultivars with better adaptive capacity to marginal environments.

Therefore, this study aimed to evaluate the effects of full and deficit irrigation levels and sowing dates on the yield, growth and development of peanut cultivated in the off-season, in order to define adequate strategies to increase yield.

\section{Material AND Methods}

The experiment was set up in the field in the traditional region of peanut production in the municipality of Jaboticabal-SP, under Aw climate (humid subtropical), according to Köppen's classification (3). The soil of the area is classified as Latossolo Vermelho Eutroférrico típico (Oxisol), with a very clayey texture, moderate A horizon, kaolinitic, on gently undulating and undulating relief (14). Its physical and chemical characteristics are presented in tables 1 and 2, respectively.

Table 1. Physical characteristics of the soil of the experimental area. Jaboticabal, SP, Brazil.

Tabla 1. Características físicas del suelo del área experimental. Jaboticabal, SP, Brasil.

\begin{tabular}{|c|c|c|c|c|c|c|}
\hline $\begin{array}{l}\text { Depth } \\
\text { (cm) }\end{array}$ & $\begin{array}{c}\mathrm{Sd}^{*} \\
\left(\mathrm{~g} \mathrm{~cm}^{-3}\right)\end{array}$ & $\begin{array}{c}\mathrm{FC}^{*} \\
\left(\mathrm{~cm}^{3} \mathbf{c m}^{-3}\right)\end{array}$ & $\begin{array}{c}\mathrm{PWP}^{*} \\
\left(\mathrm{~cm}^{3} \mathbf{c m}^{-3}\right)\end{array}$ & $\begin{array}{c}\text { Sand } \\
\left(\mathrm{g} \mathrm{kg}^{-1}\right)\end{array}$ & $\begin{array}{c}\text { Clay } \\
\left(\mathrm{g} \mathrm{kg}^{-1}\right)\end{array}$ & $\begin{array}{c}\text { Silt } \\
\left(\mathrm{g} \mathrm{kg}^{-1}\right)\end{array}$ \\
\hline $0-20$ & 1.45 & 0.45 & 0.33 & 310 & 470 & 220 \\
\hline $20-40$ & 1.49 & 0.41 & 0.30 & 270 & 520 & 200 \\
\hline
\end{tabular}

Table 2. Chemical characteristics of the soil of the experimental area. Jaboticabal, SP, Brazil. Tabla 2. Características químicas del suelo del área experimental. Jaboticabal, SP, Brasil.

\begin{tabular}{|c|c|c|c|c|c|c|c|c|c|c|c|c|}
\hline \multirow{2}{*}{$\begin{array}{c}\text { Depth } \\
\text { (cm) }\end{array}$} & \multirow{2}{*}{$\underset{\mathrm{CaCl}_{2}}{\mathbf{p H}}$} & \multirow{2}{*}{$\begin{array}{c}\mathbf{O M} \\
\left(\mathrm{g} \mathrm{dm}^{-3}\right)\end{array}$} & $\mathbf{P}_{\text {resin }}$ & $S$ & $\mathbf{H}+\mathrm{Al}$ & Al & $\mathbf{K}$ & $\mathrm{Ca}$ & Mg & SB & CCE & V\% \\
\hline & & & \multicolumn{2}{|c|}{$\left(\mathrm{mg} \mathrm{dm}^{-3}\right)$} & \multicolumn{8}{|c|}{$\left(\mathrm{mmol}_{\mathrm{c}} \mathrm{dm}^{-3}\right)$} \\
\hline $0-20$ & 5.6 & 40 & 67 & 5 & 21 & 1 & 3.4 & 36 & 13 & 52.7 & 73.9 & 71 \\
\hline $20-40$ & 5.8 & 40 & 68 & 5 & 20 & 1 & 3.2 & 36 & 11 & 50.3 & 70.4 & 71 \\
\hline
\end{tabular}

Hydrogen potential (pH), in $\mathrm{CaCl}_{2}$; Organic Matter (OM); Phosphorus Resin (Presi); Sodium (S); Potential Acidity $(\mathrm{H}+\mathrm{Al})$; Exchangeable Aluminum (Al); Potassium (K); Calcium (Ca); Magnesium (Mg); Sum of Bases (SB); Capacity Cation Exchange (CCE); Base Saturation (V\%).

Potencial de hidrógeno (pH), en $\mathrm{CaCl}_{2}$; Materia Orgánica (OM); Resina de fósforo (Presi); Sodio (S); Acidez potencial $(\mathrm{H}+\mathrm{Al})$; Aluminio intercambiable (Al); Potasio (K); Calcio (Ca); Magnesio (Mg); Suma de bases (SB); Capacidad de intercambio catiónico (CCE); Saturación de bases (V\%).

Treatments consisted of 5 depth of irrigation water applied during the growing season (L1 - 8\%, L2 - 27\%, L3 - 63\%, L4 - 94\% and L5 - 100\%), corresponding to fractions of replenishment of crop evapotranspiration (ETc), associated with two sowing dates (February - S1 and March - S2), according to figure 1 (page 58).

The experiment was carried out in a split-plot randomized complete block design, with sowing date in the plot and irrigation levels in the subplot, with four replicates. It was set up in an area of $216 \mathrm{~m}^{2}$, with 20 plots for each sowing date, totaling 40 plots. Each plot consisted of 4 crop rows with length of $2.4 \mathrm{~m}$ and evaluations were carried out in the middle portion of the two central rows. The two external rows, as well as $0.5 \mathrm{~m}$ on each end of the central rows, were considered as borders and were not used for evaluations. 


\begin{tabular}{|c|c|c|c|c|c|c|c|c|c|c|c|}
\hline \multirow{5}{*}{$\bar{n}$} & \multicolumn{11}{|c|}{ Line of sprinklers } \\
\hline & \multirow{3}{*}{$2.7 \mathrm{~m}$} & \multicolumn{5}{|c|}{ Rep. 1} & & \multicolumn{4}{|c|}{ Rep. 3} \\
\hline & & L1 & $\overline{\mathrm{L} 2}$ & L3 & L4 & L5 & $\mathrm{L5}$ & L4 & L3 & $\mathrm{L} 2$ & L1 \\
\hline & & L1 & $\mathrm{L} 2$ & $\mathrm{L3}$ & $\mathrm{L} 4$ & $\mathrm{~L} 5$ & $\mathrm{~L} 5$ & $\mathrm{~L} 4$ & $\mathrm{L3}$ & $\mathrm{L} 2$ & $\mathrm{~L} 1$ \\
\hline & \multicolumn{3}{|c|}{$2.4 \mathrm{~m}$} & ep. 2 & & & & \multicolumn{4}{|c|}{ Rep. 4} \\
\hline
\end{tabular}

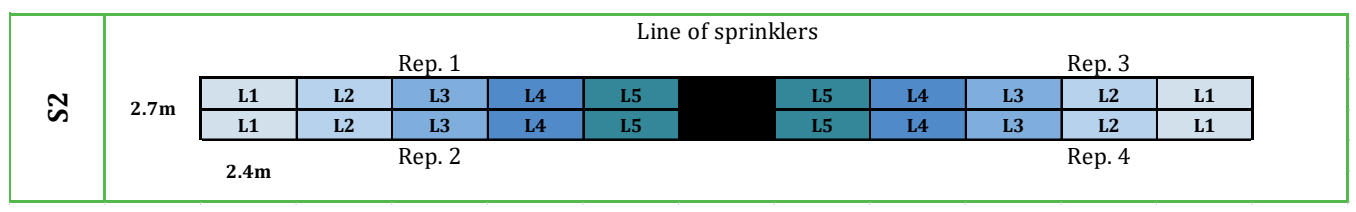

Figure 1. Scheme of the experimental area, with line of sprinklers and experimental units with treatments of irrigation depths (L1 - 8\%, L2 - 27\%, L3 - 63\%, L4 - 94\% and L5 - 100\% replenishment of crop evapotranspiration) and sowing dates (S1 - February and S2 - March).

Figura 1. Esquema del área experimental, con línea de aspersores y unidades experimentales con tratamientos de láminas de riego (L1 - 8\%, L2 - 27\%, L3 - 63\%, L4 94\% y L5 - 100\% de reposición de evapotranspiración del cultivo) y fechas de siembra

(S1 - febrero y S2 - marzo).

The adequate temperature range for peanut growth is considered by some authors to be between $10{ }^{\circ} \mathrm{C}$ and $33{ }^{\circ} \mathrm{C}(4,29)$. In the present experiment, the temperature values remained within the acceptable range, except for the minimum temperature, which reached values below the lower limit in mid-May and late June (figure 2A, page 59). In mid-May, the crop sown in February was at the full seed stage (R6), while the crop sown in March was at the early pod formation stage (R3). At the end of June, the crops sown in S1 and S2 were at the harvest stage (R8) and full seed stage (R6), respectively. The average temperatures in the first cropping cycle were higher than those of the second one $\left(22.8\right.$ and $21.9^{\circ} \mathrm{C}$, respectively), as shown in figure $2 \mathrm{~A}$ (page 59). When the averages are compared considering the first 90 days of each cropping cycle, the difference of temperature was even greater for the first one $\left(24.1^{\circ} \mathrm{C}\right)$, compared to the second one $\left(22.8^{\circ} \mathrm{C}\right)$.

ETc was calculated as the product between crop coefficient (Kc) and reference evapotranspiration (ETo), with Kc values interpolated during the phenological cycle (i.e. $\mathrm{Kc}_{\text {initial }}=$ $0.4, \mathrm{Kc}_{\text {mid }}=1.15$ and $\mathrm{Kc}_{\text {final }}=0.6$ ) and ETo calculated by the Penman-Monteith method (2), using daily meteorological data from the weather station of FCAV-UNESP, located close to the experimental area.

During the experimental period, the rainfall and number of days with rainfall were lower than the average of the last 40 years. This water deficit condition allowed evaluating the effects of the treatments imposed on the crop, as it will be discussed below. In the first cropping cycle, there was no need for water supplementation during the vegetative stage (V1 to V6), because of the rain occurred (figure 2B, page 59). In the second cropping cycle, water replacement was necessary at 20 days after sowing (DAS). There were rains in February and March, followed by a long dry period until the end of July, which coincided with most of the cycle for the crop sown in March. Irrigation was applied every week from March, according to the quantities recommended in each treatment. For the crop sown in February, the highest values of ETc ( 4 to $5 \mathrm{~mm} \mathrm{day}^{-1}$ ) occurred from March 10 to March 31 (figure 2C, page 59), coinciding with high temperatures in the period (figure 2A, page 59). For the crop sown in March, the highest values of ETc were between 3 and $4 \mathrm{~mm}^{-1 a y}{ }^{-1}$ for the period from April 20 to May 20 (figure 2C, page 59). 

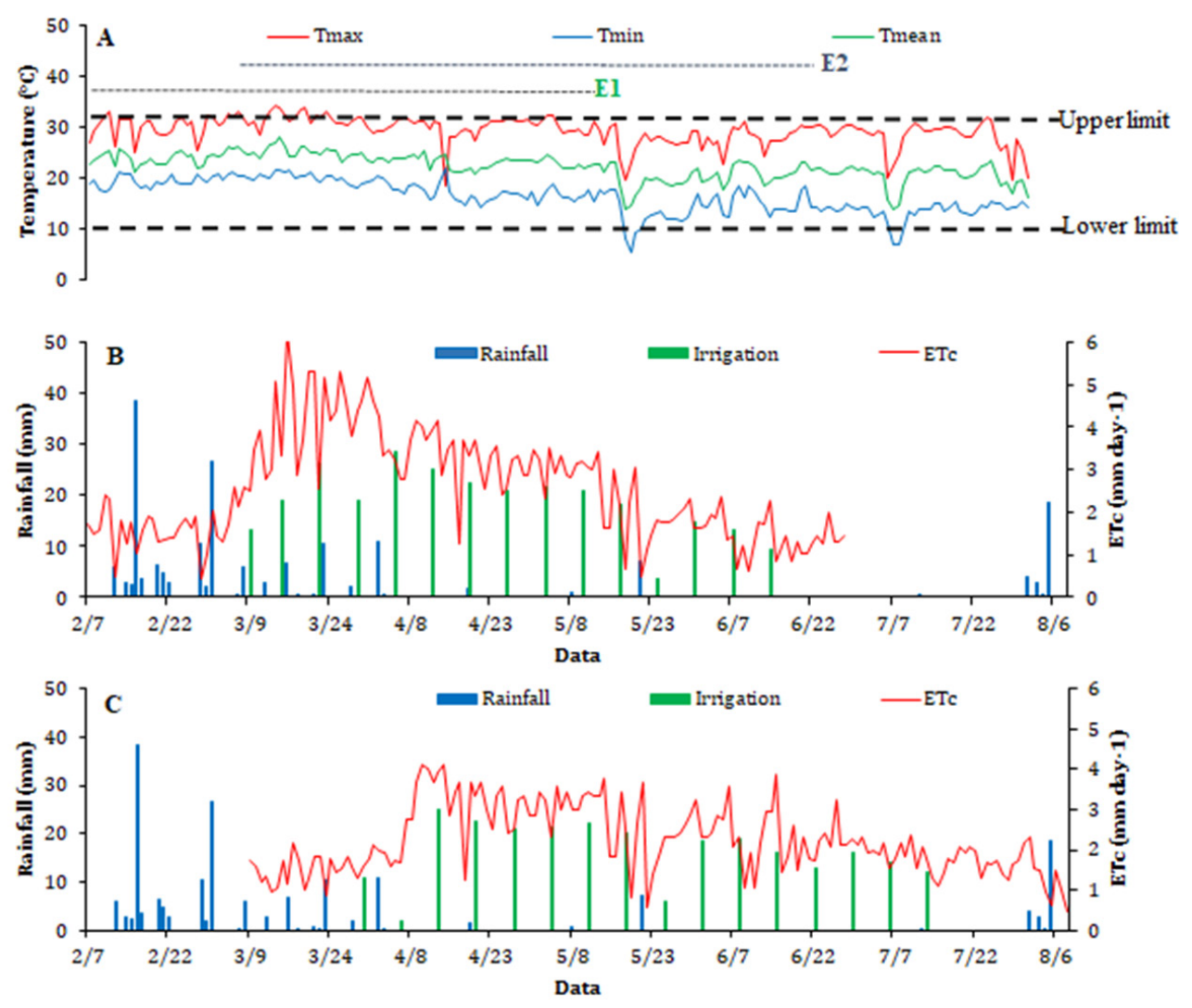

Figure 2. Maximum (Tmax), mean (Tmed) and minimum (Tmin) temperatures (A) and rainfall, crop evapotranspiration (ETc) and irrigation applied in the treatment with full irrigation (L5) for sowing in February (B) and March (C).

Figura 2. Temperaturas máximas (Tmax), medias (Tmed) y mínimas (Tmin) (A) y lluvia, evapotranspiración del cultivo (ETc) y riegos aplicados en el tratamiento con riego completo (L5) para siembra en febrero (B) y marzo (C).

The accumulated values of rainfall were 157 and $51 \mathrm{~mm}$ and of ETc were 323 and $299 \mathrm{~mm}$, for the crops sown in February and March, respectively (figure 3, page 60). Most of the rainfall in the first cropping cycle occurred in February (about $100 \mathrm{~mm}$ ), coinciding with the initial stages of the crop (V1 to V6). The irrigation depths were similar and ranged from 66 to $314 \mathrm{~mm}$ in the first cropping cycle and from 65 to $310 \mathrm{~mm}$ in the second one. Consequently, the total depths (rainfall + irrigation) received in the treatments ranged from 223 to $470 \mathrm{~mm}$ in the first cropping cycle and from 116 to $360 \mathrm{~mm}$ in the second cropping cycle (figure 3, page 60). This difference was due to the rainfall, since the irrigation depths applied were similar for both sowing seasons. The maximum total depths received in this experiment were lower than those reported in other studies, in which the peanut crop requires at least $500 \mathrm{~mm}$ during the crop cycle (20). This difference is due to the lower water demand of the crop in the autumn-winter period, as conducted in this experiment.

Irrigation was applied weekly in quantities corresponding to the fractions of the ETc accumulated in the period in each treatment, considering an 85\% application efficiency. Water depths in each treatment were applied using a line-source sprinkler system (17), which allows obtaining a decreasing gradient of water depth perpendicular to the irrigation line, corresponding to the distribution factor (figure 4, page 60), as established in the treatments (figure 1, page 58). The experiment used Senninger ${ }^{\circledR} 3023-2$ sprinklers and M 08Qx05 3/4" nozzles, spaced every $6 \mathrm{~m}$ in the central row and operated with $350 \mathrm{kPa}$ pressure. The distribution factors of the sprinklers were determined in a field test using collectors spaced by $1 \mathrm{~m}$ up to the limit distance of water application by the sprinklers, perpendicularly to the irrigation line, with 2 replicates. 

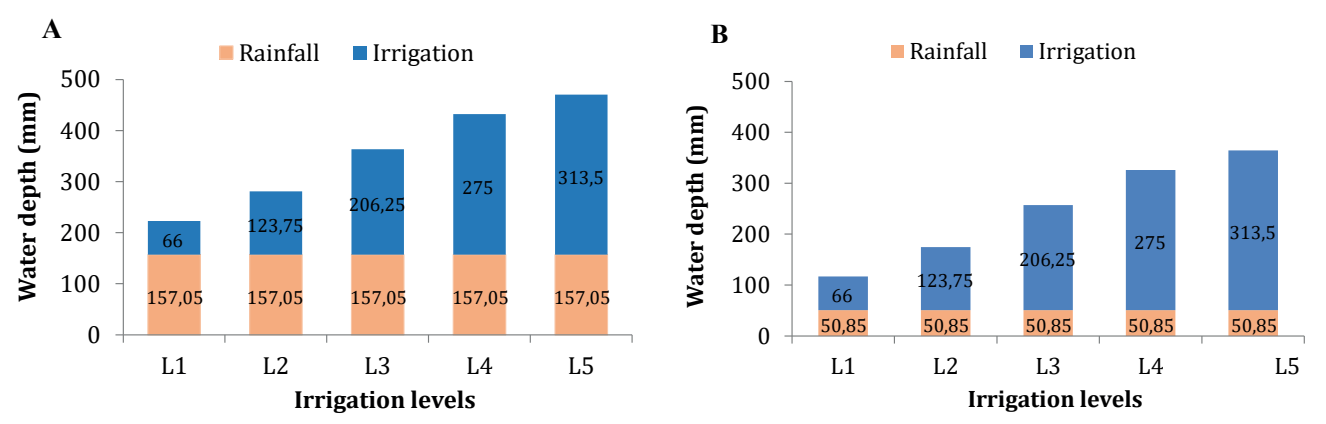

Figure 3. Seasonal water depths (irrigation + rainfall) as a function of irrigation levels (L1 - 8\%, L2 - 27\%, L3 - 63\%, L4 - 94\% and L5 - 100\% replenishment of crop evapotranspiration) and sowing dates (February (A) and March (B)).

Figura 3. Láminas de agua estacionales (riego + lluvia) en función de los niveles de riego (L1 - 8\%, L2 - 27\%, L3 - 63\%, L4 - 94\% y L5 - 100\% de reposición de la evapotranspiración del cultivo) y las fechas de siembra (febrero (A) y marzo (B)).

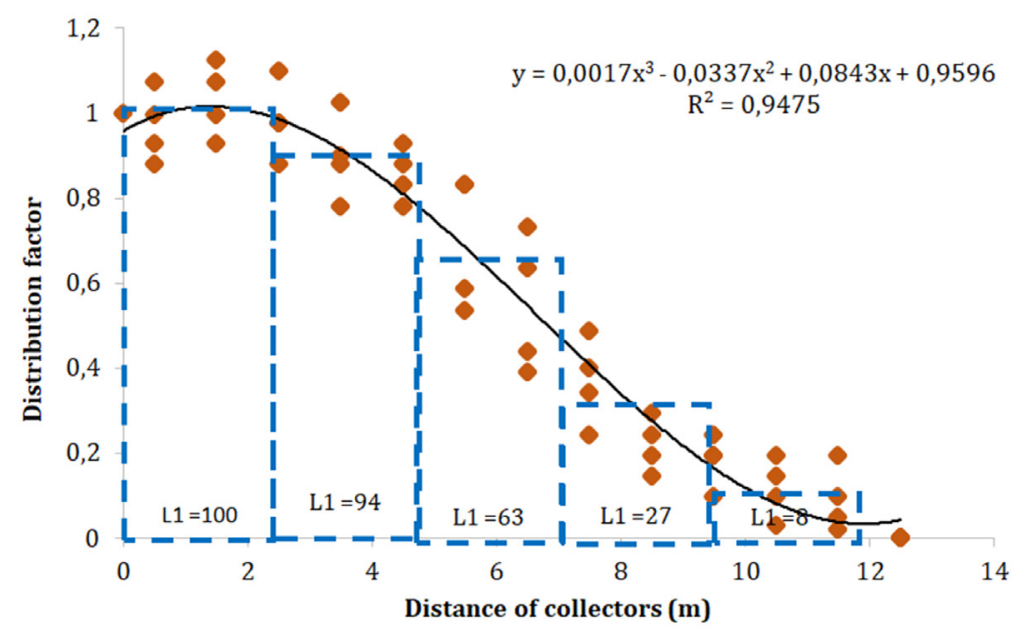

Figure 4. Distribution factor of the irrigation depths applied by the line-source sprinkler system.

Figura 4. Factor de distribución de las láminas de riego aplicadas por el sistema de aspersores de fuente de línea.

The sowing dates were February 6 and March 6, 2018. The cultivar IAC 505, which has a spreading growth habit, cycle between 130 and 140 days, moderate resistance to leaf diseases and relative drought tolerant (16). The crop was sown at spacing of $0.9 \mathrm{~m}$ between rows and density of 15 seeds $\mathrm{m}^{-1}$. At sowing, fertilization was applied using the 0-20-20 (N, P, K) formulation at dose of $300 \mathrm{~kg} \mathrm{ha}^{-1}$. Seeds were previously treated with the fungicide Thiram (Vitavax ${ }^{\circledR}$-Thiram 200 SC, 250 mL of c.p. $100 \mathrm{~kg}^{-1}$ ) to avoid the incidence of pathogens. In order to maintain the phytosanitary control of the experiment, weekly fungicide applications were carried out with the following active ingredients: Pyraclostrobin + Epoxiconazole (Opera ${ }^{\circledR}$ ) and Cyproconazole (Alto ${ }^{\circledR} 100$ ), at doses of $109.8 \mathrm{~g} \mathrm{a.i.} \mathrm{ha}^{-1}$, $720 \mathrm{~g}$ a.i. ha ${ }^{-1}$ and 25 g a.i. ha-1 ${ }^{-1}$ respectively. The insecticide Thiamethoxam (Engeo Pleno ${ }^{\mathrm{TM}} \mathrm{S}$ ) was also used at dose of $115 \mathrm{~g}$ a.i. ha-1 and weeds were controlled by manual weeding to avoid interference with the crop.

The following agronomic characteristics of the crop were evaluated from 20 days after sowing (DAS) until harvest: a) plant height - main stem height was measured in five plants of each experimental unit; b) Canopy cover fraction- measured by pictures taken from the experimental plots and analyzed by the Canopeo® software, (26); c) Intercepted photosyn- 
thetically active radiation fraction (IRF) - calculated as the ratio of Photosynthetically active radiation (PAR) measured above and below the crop canopy by means of a bar with a linequantum sensor (AccuPAR radiometer; Decagon Devices, Inc., Pullman, WA), with measurements taken between 11 am and $2 \mathrm{pm}$, by placing the bar above the canopy and below the green leaves, making four measurements per plot; d) pod yield - plants in the evaluated area of each plot were threshed at the end of the cycle to separate the pods and then determine their mass; e) unit seed mass was determined using a sample from the five plants of the plot, according to the Rules for Seed Analysis (9); f) degree-days (DD, ${ }^{\circ} \mathrm{C}$ ) - computed as the sum of positive values calculated by equation 1 :

$$
D D=\left(\frac{T \max -\operatorname{Tmin}}{2}\right)-T b
$$

where:

Tmax and Tmin are maximum and minimum daily temperature, respectively $\left({ }^{\circ} \mathrm{C}\right)$

$\mathrm{Tb}$ is base temperature $\left(12^{\circ} \mathrm{C}\right)$;

g) irrigation water productivity (IWP, $\mathrm{kg} \mathrm{m}^{-3}$ ) - calculated by equation 2 as the pod yield produced per unit of applied irrigation water (1).

$$
I W P=\frac{Y_{i}}{10 D_{i}}
$$

where:

$\mathrm{Y}_{\mathrm{i}}$ is the yield $\left(\mathrm{kg} \mathrm{ha}^{-1}\right)$ of the crop attained with seasonal irrigation depth $\mathrm{D}_{\mathrm{i}}(\mathrm{mm})$.

The results were subjected to analysis of variance (ANOVA) by $\mathrm{F}$ test and the means were compared by Tukey test at 5\% probability level, using Agrostat software (7).

\section{RESUlts}

The phenological cycle, from sowing to physiological maturity (S to R7) ended at 117 and 142 DAS for the crops sown in February and March, respectively, totaling 1,288 and 1,282 DD (degree-days) (figure 5). In both seasons, the vegetative stage (VE-R1) had a similar duration (35 days and 431 and 447 DD). The duration of the reproductive stage (R1-R7) was 75 and 100 days with 857 and 835 DD for the first and second sowing dates, respectively (figure 5 ).
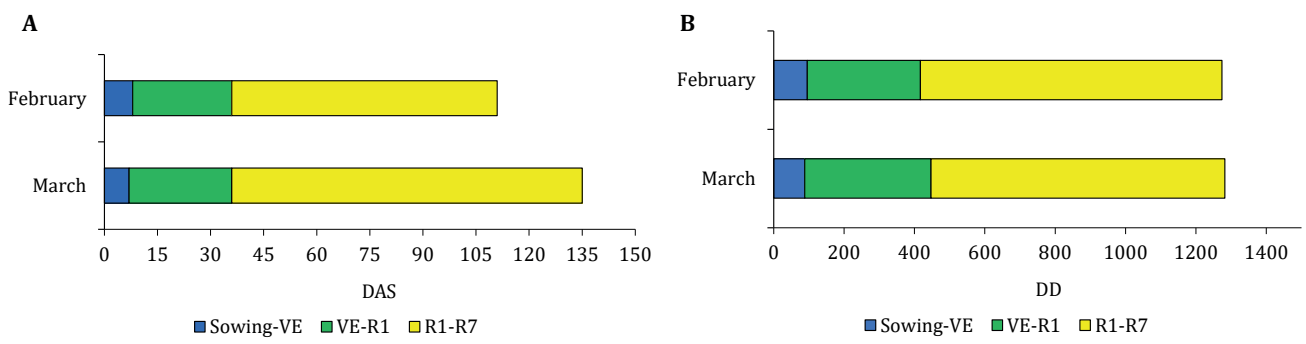

Figure 5. Phenological cycle of the cultivar IAC 505 in days after sowing (DAS) (A) and degree-days (DD) (B), for sowing in February and March.

Figura 5. Ciclo fenológico del cultivar IAC 505 en días después de la siembra (DAS) (A) y grados-días (DD) (B), para siembra en febrero y marzo.

Plant height was similar for all treatments until flowering (R1), however, for the reproductive stage, plants receiving higher irrigation application had increased growth rates, reaching $30 \mathrm{~cm}$ for treatment L1, compared to $18 \mathrm{~cm}$ for L5, for both, S1 and S2 planting dates (figure 6, page 62). 
A

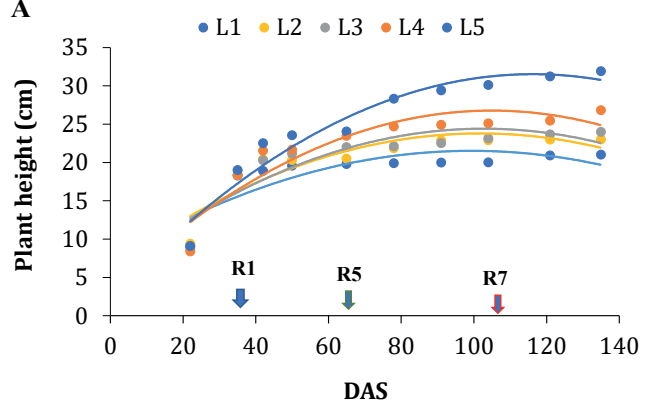

B

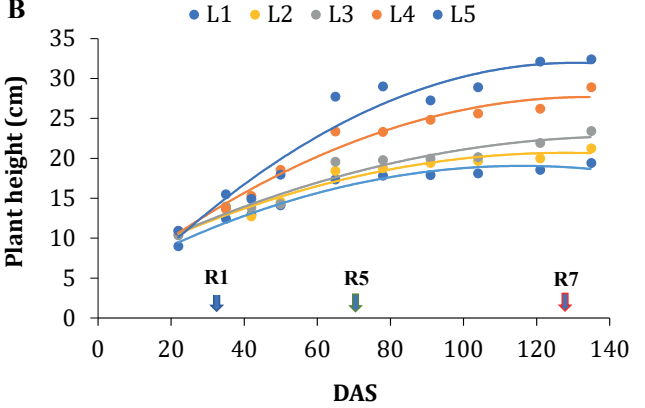

Figure 6. Plant height as a function of the level of irrigation water applied (L1 $=8 \%$, $\mathrm{L} 2=27 \%, \mathrm{~L} 3=63 \%, \mathrm{~L} 4=94 \%$ and $\mathrm{L} 5=100 \%$ replenishment of crop evapotranspiration), for peanut sown in February (A) and March (B). R1, R5 and R7 are flowering, pod formation and physiological maturity stages, respectively.

Figura 6. Altura de la planta función del nivel de agua de riego aplicado (L1 = 8\%, L2 $=27 \%, \mathrm{~L} 3=63 \%, \mathrm{~L} 4=94 \%$ y L5 = 100\% de reposición de la evapotranspiración del cultivo), para maní sembrado en febrero (A) y marzo (B)). R1, R5 y R7 son etapas de floración, formación de vainas y madurez fisiológica, respectivamente.

Canopy cover fraction had similar behavior to plant height, with the effects of irrigation levels becoming evident from flowering, followed by maximum canopy cover in mid grain filling period, corresponding to 70 to $80 \%$ for L1 and L2, as compared to 40 to $50 \%$ for L4 and L5 (figure 7). Slower senescence was observed in the treatments with higher irrigation depths. The aerial view taken at maximum canopy cover (65 DAS) also show the treatment's effect by relating the gradual increase in canopy cover and intercepted radiation with increase in irrigation depth (figure 8, page 63).
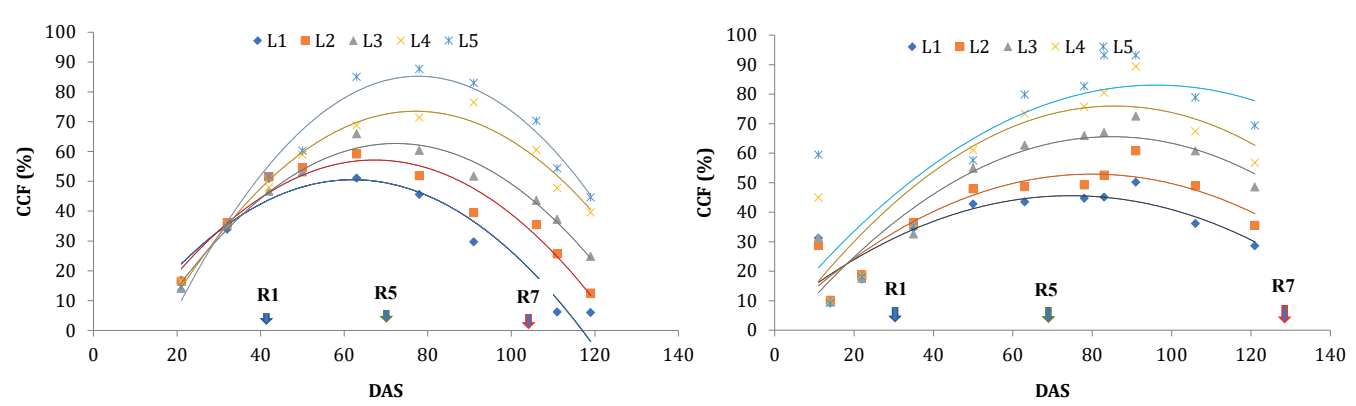

Figure 7. Canopy cover fraction as a function of the level of irrigation applied (L1 $=8 \%$, $\mathrm{L} 2=27 \%, \mathrm{~L} 3=63 \%, \mathrm{~L} 4=94 \%$ and $\mathrm{L} 5=100 \%$ replenishment of crop evapotranspiration), for peanut sown in February (A) and March (B). R1, R5 and R7 are flowering, pod formation and physiological maturity stages, respectively.

Figura 7. Fracción de la cubierta del dosel en función del nivel de riego aplicado (L1 $=8 \%$, L2 $=27 \%, \mathrm{~L} 3=63 \%, \mathrm{~L} 4=94 \%$ y L5 $=100 \%$ de reposición de la evapotranspiración del cultivo), para el maní sembrado en Febrero (A) y marzo (B). R1, R5 y R7 son etapas de floración, formación de vainas y madurez fisiológica, respectivamente.

Unit seed mass increased linearly with the increase in the water depth received in both cropping cycles, ranging from 0.60 to $0.80 \mathrm{~g}$ (figure 9A, page 63). Similarly, pod yield also increased linearly with the increase in water depth, from about 1,500 $\mathrm{kg} \mathrm{ha}^{-1}$, in both cropping cycles, to $4,141 \mathrm{~kg} \mathrm{ha}^{-1}$ in the first one and to $5,102 \mathrm{~kg} \mathrm{ha}^{-1}$ in the second one (figure 9B, page 63). 


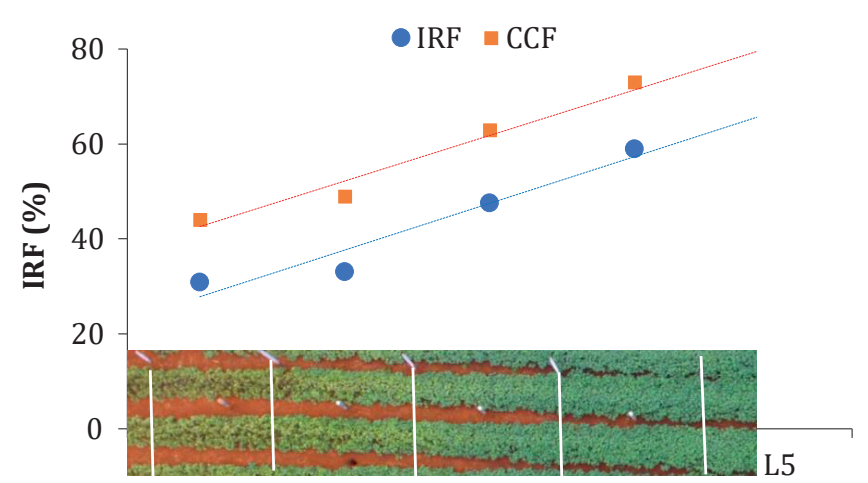

Irrigation levels

Figure 8. Intercepted photosynthetically active radiation fraction (IRF), canopy cover fraction (CCF) and aerial view of plots at 65 days after sowing for the irrigation levels applied (L1 $=8 \%, \mathrm{~L} 2=27 \%, \mathrm{~L} 3=63 \%, \mathrm{~L} 4=94 \%$ and $\mathrm{L} 5=100 \%$ replenishment of crop evapotranspiration) for peanut sown in February.

Figura 8. Fracción de radiación interceptada (IRF), fracción de cobertura del dosel (CCF) y vista aérea de las parcelas a los 65 días después de la siembra para los niveles de riego aplicados ( $\mathrm{L} 1=8 \%, \mathrm{~L} 2=27 \%, \mathrm{~L} 3=63 \%, \mathrm{~L} 4=94 \%$ y L5 = 100\% de reposición de la evapotranspiración del cultivo) para el maní sembrado en febrero.

A
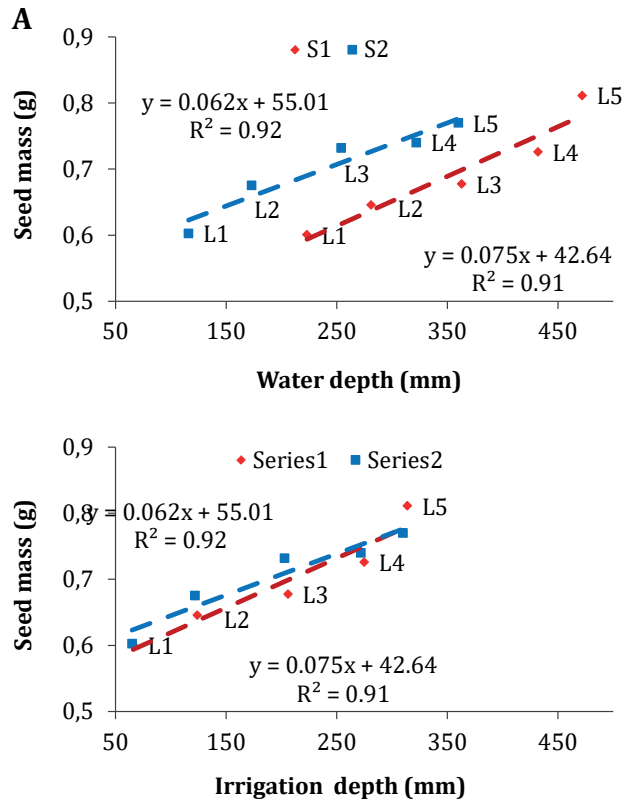
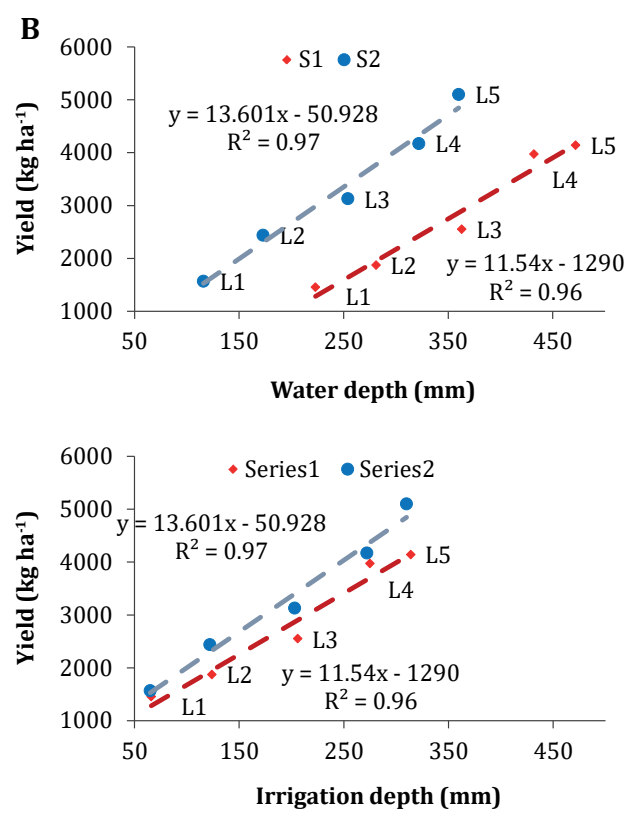

Figure 9. Unit seed mass (A) and pod yield (B) for peanut sown in February (S1) and March (S2), as a function of the seasonal water depth (rainfall + irrigation) and irrigation water depth, according to the level of irrigation (L1 - 8\%, L2 - 27\%, L3 - 63\%, L4 - 94\% and L5 - 100\% replenishment of crop evapotranspiration).

Figura 9. Massa de semillas (A) y rendimiento de vaina (B) para el maní sembrado en febrero (S1) y marzo (S2), en función de la profundidad del agua estacional (lluvia + riego) y la profundidad de agua riego, según el nivel de riego (L1 - 8\%, L2 - 27\%, L3 - 63\%, L4 $94 \%$ y L5 - 100\% de reposición de la evapotranspiración del cultivo).

The analysis of variance for pod yield showed significant effects $(p \geq 0.01)$ of sowing date, irrigation levels and the interaction between these factors (table 3, page 64). Pod yield was higher in the second cropping cycle, compared to the first one, at the irrigation levels 
L2 (30\%), L3 (23\%) and L5 (23\%), and similar at the other levels. For the same sowing date, reducing irrigation application caused significant reductions on yield at all irrigation levels, except for L4 and L5 in the first cropping cycle, indicating similarity between the water depths of $94 \%$ and $100 \%$ ETc, which correspond to 275 and $314 \mathrm{~mm}$, respectively. Such $12 \%$ saving in the applied water depth represents lower cost of production without losses in the yield of this cultivar. However, this effect did not occur in the second cropping cycle, since the application of water depths of the same magnitude as those applied in the first one for the treatments L4 and L5 (272 and $310 \mathrm{~mm}$, respectively) resulted in a 22\% reduction of yield.

Table 3. Analysis of variance and comparing means for pod yield $\left(\mathrm{kg} \mathrm{ha}^{-1}\right)$ as a function of irrigation level $(\mathrm{L} 1=8 \%, \mathrm{~L} 2=27 \%, \mathrm{~L} 3=63 \%, \mathrm{~L} 4=94 \%$ and $\mathrm{L} 5=100 \%$ replenishment of crop evapotranspiration) and sowing date.

Tabla 3. Análisis de varianza y medias de comparación para el rendimiento de vainas $\left(\mathrm{kg} \mathrm{ha}^{-1}\right.$ ) en función del nivel de riego (L1 = 8\%, L2 = 27\%, L3 = 63\%, L4 = 94\% y L5 = 100\% de reposición de evapotranspiración del cultivo) y fechas de siembra.

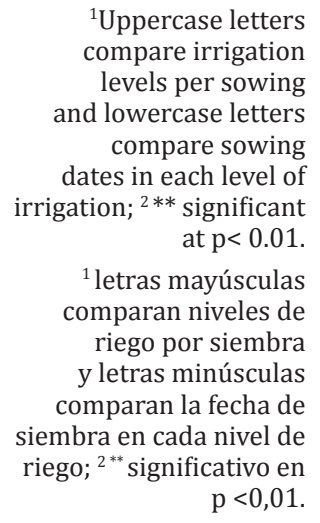
$\mathrm{p}<0,01$.

\begin{tabular}{|c|c|c|c|c|c|c|}
\hline Sowing \Irrigation & L1 & L2 & L3 & L4 & L5 & Mean \\
\hline February & $1.454 \mathrm{Da}$ & $1.873 \mathrm{Cb}$ & $2.550 \mathrm{Bb}$ & $3.971 \mathrm{Aa}$ & $4.141 \mathrm{Ab}$ & 2.798 \\
\hline March & $1.568 \mathrm{Ea}$ & $2.436 \mathrm{Da}$ & $3.129 \mathrm{Ca}$ & $4.172 \mathrm{Ba}$ & $5.102 \mathrm{Aa}$ & 3.281 \\
\hline Mean & 1.511 & 2.154 & 2.839 & 4.072 & 4.622 & 3.031 \\
\hline ANOVA $^{2}$ & \multicolumn{5}{|c|}{$39.86^{* *}$} \\
\hline Sowing (S) & \multicolumn{5}{|c|}{$334.08^{* *}$} \\
\hline Irrigation (L) & \multicolumn{5}{|c|}{$7.70^{* *}$} \\
\hline S x L & \multicolumn{7}{|c|}{6.60} \\
\hline CV\% (S) & \multicolumn{7}{|c}{} \\
\hline CV\% (L) & \multicolumn{7}{|c}{} \\
\hline
\end{tabular}

The amount of irrigation required to produce the same mass of pods was larger in the first crop period, indicating lower productivity of the irrigation water compared to the second crop period (figure 10).

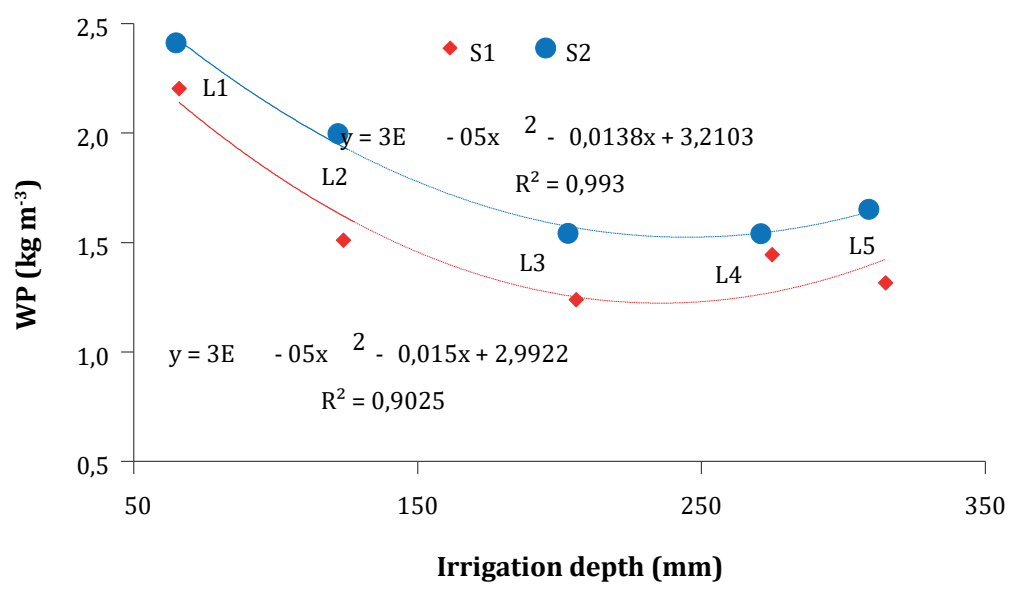

Figure 10. Water productivity (WP) for sowing in February (S1) and March (S2), as a function of the seasonal irrigation depth, according to the level of irrigation (L1 - 8\%, L2 -

27\%, L3 - 63\%, L4 - 94\% and L5 - 100\% replenishment of crop evapotranspiration).

Figura 10. Productividad del agua (WP) para siembra en febrero (S1) y marzo (S2), en función de la profundidad riego estacional, según el nivel de riego (L1 - 8\%, L2 - 27\%, L3 63\%, L4 - 94\% y L5 - 100\% de reposición de la evapotranspiración del cultivo). 


\section{DISCUSSION}

Peanut crop is considered as a day-neutral plant with respect to photoperiodism, in which day length does not affect flowering, whereas phenological stage duration is dependent on-air temperature (15). The crop cycles in this experiment were close to the cycle duration for the cultivar IAC 505, which is 130 to 140 days (16). Because of similar temperature in both planting dates (figure $2 \mathrm{~A}$, page 59 ), vegetative stage duration had no difference (figure 5A, page 61). Reproductive stage was 25 days shorter in the crop sown in February, as compared to March. This effect might be due to the higher temperature during the first crop cycle (figure 2A, page 59), as given by the sum of DD (figure 5B, page 61), while in the cycle of the crop sown in March, the days with temperatures lower than the base temperature resulted in lower thermal sum, delaying the physiological stages.

The irrigation levels did not affect plant height and canopy cover in the vegetative stage, because of the low crop water demand in the first stages, since plant size (figure 6, page 62) and canopy cover (figure 7, page 62) were small. Therefore, the low water depths applied, in addition to rainfall, were enough to meet crop water demand and not caused delay in the stage VE to R1. During the reproductive stage, the varying irrigation depths applied in the treatments provided sufficient water supply for the treatments L4 and L5 an increasing gradual water deficit for the treatments L1 to L3, due to lower replenishment of crop consumptive use. Consequently, lower growth rates in height and canopy cover were observed in the treatments with water deficit, which can be attributed to the reduction of turgor, which in turn directly affects plant growth. Those results corroborate Larcher (2006) and Suleiman et al. (2013).

The close correlation between canopy cover fraction and intercepted radiation by the canopy (figure 8, page 63) makes evident that the higher values measured for canopy cover fraction during the crop cycle correspond to increase in biomass, as irrigation application increased from L1 to L5. In fact, abiotic stress factors, such as water stress, can cause changes in plant growth and metabolism since the beginning of the development cycle, leading to reductions in the capture of solar radiation and, consequently, lower growth rate and reduction in crop yield $(10,25)$.

The increments on yield obtained between the highest and lowest levels of water replacement (L5 and L1) were around 3 times for both sowing dates (figure 9B, page 63). The difference in irrigation water productivity (figure 10, page 64) was due to the lower yields of the first cropping cycle (table 3, page 64 and figure 9B, page 63), since applied seasonal irrigation depths were similar (figure 3, page 60).

Higher pod yield in the second cropping cycle may be due to the duration of the reproductive stage (R1-R7), which was 25 days longer than that of the first cropping cycle (figure 5, page 61), because of the lower crop development rate under milder temperature. Studies on plant development demonstrate that the increase in temperature affects grain yield because of the reduction in the duration of the phenological stages (32), especially the reproductive stage (8), resulting in smaller seeds and lower yields (13).

The result of reduction in yield due to water stress agrees with Kheira et al. (2009) and Azevedo et al. (2017), who concluded that water suppression at any stage of the peanut cycle causes a reduction in its yield. According to Nakagawa and Rosolem (2011), peanut sensitivity to water stress is lower in the period from seedling emergence to early formation of the floral organs and expressively increases during the flowering and fruiting stages, which occurred in the treatments with deficit irrigation for both sowing dates. These results also corroborate those observed by Barbieri et al. (2017), who found differences in the yields of the cultivars IAC Tatu (erect) and Runner IAC 886 (dwarf) under water replacement levels.

The yields obtained at the higher irrigation levels (L4 and L5) were similar or superior to the yield obtained in the rainy season in the farms of the region of the experimental area (12), which was $3,798 \mathrm{~kg} \mathrm{ha}^{-1}$. For the dry season, the estimated yield for the region of Jaboticabal was $1,541 \mathrm{~kg} \mathrm{ha}^{-1}$, which is equivalent to the values observed at the lowest level of water replenishment (L1).

Although promising, the results of this study are not sufficient to recommend the practice of irrigation in peanut cultivation on a large scale. It is still necessary conduct studies over longer periods and in other producing regions to evaluate the productive potential and economic viability of irrigated cultivation. 


\section{ConCLUSIONS}

In the absence of water deficit, peanut yield was 30\% higher for sowing in March than for sowing in February. Water deficit reduced plant height, leaf area, mass of seeds and pod yield and increase crop cycle. Adequate water supply promoted by full irrigation (L5) led to yields from 4.141 to $5.102 \mathrm{~kg} \mathrm{ha}^{-1}$, for sowing in February and March, respectively, which were approximately three times higher than those obtained with the lowest level of irrigation (L1).

\section{REFERENCES}

1. Ali, M. H.; Hoque, M. R., Hassan, A. A.; Khair, A. 2007. Effects of deficit irrigation on yield, water productivity, and economic returns of wheat. Agricultural Water Management. 92(3): 11-210.

2. Allen, R. G.; Pereira, L. S.; Raes, D.; Smith, M. 1998. Crop evapotranspiration-Guidelines for computing crop water requirements. FAO Irrigation and drainage paper 56. Rome.

3. Alvares, C. A.; Stape, J. L.; Sentelhas, P. C.; Gonçalves, J. L. M.; Sparovek, G. 2013. Köppen's climate classification map for Brazil. Meteorologische Zeitschrift. 22: 711-728.

4. Awal, M. A.; Ikeda, T. 2003. Controlling canopy formation, flowering, and yield in field-grown stands of peanut (Arachis hypogaea L.) with ambient and regulated soil temperature. Field crops research. 81:121-132.

5. Azevedo, B. M.; Sousa, G. G.; Paiva, T. F. P.; Mesquita, B. R.; Viana, T. V. A. 2017. Manejo da irrigação na cultura do amendoim. Magistra. 26:11-18.

6. Barbieri, J. D.; Dallacort, R.; Faria Junior, C. A.; Freitas, P. S.; Carvalho, M. A. 2017. Peanut cultivars submitted to irrigation levels and nitrogen adubation in tropical climate. Engenharia Agrícola. 37: 1126-1136.

7. Barbosa, J. C.; Maldonado Júnior, W. 2015. AgroEstat: sistema para análises estatísticas de ensaios agronômicos. Jaboticabal, FCAV/UNESP. 396 p.

8. Boote, K. J. 2011. Improving soybean cultivars for adaptation to climate change and climate variability. In Crop adaptation to climate change. London: Wiley. p. 371-395.

9. Brasil. Ministério da Agricultura, Pecuária e Abastecimento. 2009. Regras para análises de sementes. Brasília: MAPA/SDA/ACS.

10. Castro, C. R. T.; Garcia, R. 1996. Competição entre plantas com ênfase no recurso luz. Ciência Rural. 26: $167-174$.

11. Chartzoulakis, K.; Bertaki, M. 2015. Sustainable water management in agriculture under climate change. Agriculture and Agricultural Science Procedia. 4: 88-98.

12. Conab. Companhia Nacional de Abastecimento, 2018. Acompanhamento da safra brasileira de grãos. Safra 2017/18 décimo primeiro levantamento 2018. v. 5. №11. (Accessed 2018 October 19). https://www.conab.gov.br/info-agro/safras/graos>

13. Egli, D. B.; Wardlaw, I. F. 1980. Temperature response of seed growth characteristics of soybeans. Agronomy Journal. 72: 560-564.

14. Embrapa. Empresa Brasileira de Pesquisa Agropecuária. 2013. Sistema brasileiro de classificação de solos. Brasília: Embrapa.

15. Ferrari, N.; Costa, C. H. M; Castro, G. S. A. 2012. Ecofisiologia do amendoim. Scientia Agraria Paranaensis. 11: 01-13.

16. Godoy, I. J. D.; Santos, J. F. D.; Michelotto, M. D.; Moraes, A. R. A. D.; Bolonhezi, D.; Freitas, R. S. D.; Martins A. L. M. 2017. IAC OL 5-New high oleic runner peanut cultivar. Crop Breeding and Applied Biotechnology. 17: 295-298.

17. Hanks, R. J.; Keller, J.; Rasmussen, V. P.; Wilson, G. D. 1976. Line source sprinkler for continuous variable irrigation-crop production studies. Soil Science Society of America Journal. 40: 426-429.

18. Jain, N. K.; Jat, R. A.; Yadav, R. S.; Bhaduri, D.; Meena, H. N. 2018. Polythene mulching and fertigation in peanut (Arachis hypogaea L.): Effect on crop productivity, quality, water productivity and economic profitability. Indian Journal of Agricultural Sciences. 88: 1168-78.

19. Kambiranda, D. M.; Vasanthaiah, H. K.; Ananga, R. K. A.; Basha, S. M.; Naik, K. 2011. Impact of drought stress on peanut (Arachis hypogaea L.) productivity and food safety. In H. Vasanthaiah (Ed.). Plants and environment. Intech (p 249-272). http://www.intecho-pen.com/ books/plants-and-environment/impact-of-drought-stress-onpeanut-arachis-hypogaealproductivity-and-food-safety

20. Ketring, D. L. 1991. Physiology of oil seeds: effects of water deficit on peanut seed quality. Crop Science. 31:459-463.

21. Kheira, A. A. A. 2009. Macromanagement of deficit-irrigated peanut with sprinkler irrigation. Agricultural Water Management. 96: 1409-1420.

22. Kramer, P. J.; Boyer, J. S. 1995. Water relations of plants and soils. London: Academic press.

23. Larcher, W. 2006. Ecofisiologia vegetal. São Carlos: RIMA.

24. Nakagawa. J.; Rosolem, C. A. 2011. O amendoim: tecnologia de produção. Bauru: Fepaf, 1. 
25. Ni, H.; Moody, K.; Robles, R. P.; Paller, E. C.; Lales J. S. 2000. Oryza sativa plant traits conferring competitive ability against weeds. Weed Science. 48: 200-204.

26. Patrignani, A.; Ochsner, T. E. 2015. Canopeo: A powerful new tool for measuring fractional green canopy cover. Agronomy Journal. 107: 2312-2320.

27. Pereira. J. W.; Melo Filho, P. A.; Albuquerque, M. B.; Nogueira, R. M.; Santos, R. C. 2012. Mudanças bioquímicas em genótipos de amendoim submetidos a déficit hídrico moderado. Revista Ciência Agronômica. 43: 766-773.

28. Pereira. J. W. L.; Albuquerque, M. B.; Melo Filho, P. A.; Nogueira, R. J. M. C.; Lima, L. M.; Santos, R. C. 2016. Assessment of drought tolerance of peanut cultivars based on physiological and yield traits in a semiarid environment. Agricultural Water Management. 166: 70-76.

29. Prela, A.; Ribeiro, A. M. A. 2000. Soma de graus-dia para o sub-período semeadura maturação do amendoinzeiro. Revista Brasileira de Agrometeorologia. 8: 321-324.

30. Reddy, A. R.; Chaitanya, K. V.; Vivekanandan, M. 2004. Drought-induced responses of photosynthesis and antioxidant metabolism in higher plants. Journal of plant physiology. 161: 1189-1202.

31. Santos R.; Freire, R.; Lima, L. 2013. 0 Agronegócio do Amendoim no Brasil. Brasília: Embrapa.

32. Seddigh, M.; Jolliff, G. D. 1984. Night temperature effects on morphology, phenology, yield and yield components of indeterminate field-grown soybean. Agronomy Journal. 76: 824-828.

33. Suleiman, A. A.; Soler, C. M. T.; Hoogenboom, G. 2013. Determining FAO-56 crop coefficients for peanut under different water stress levels. Irrigation Science. 31: 169-178.

34. Thangthong, N.; Jogloy, S.; Jongrungklang, N.; Kvien, C. K.; Pensuk, V.; Kesmala, T.; Vorasoot. N. 2018. Root distribution patterns of peanut genotypes with different drought resistance levels under early-season drought stress. Journal of Agronomy and Crop Science. 204: 111-122.

35. USDA. United States Department of Agriculture. 2018. Foreign Agricultural Service. World Agricultural Production. 2017. Circular Series. (Aceessed 2018). https://apps.fas.usda. gov/psdonline/circulars/production.pdf

\section{ACKNOWLEDGEMENTS}

The first author acknowledges the financial grant of CAPES - Coordenação de Aperfeicoamento de Pessoal de Nivel Superior. 